OPEN ACCESS

Edited by:

Angela Wahl,

University of North Carolina at Chapel Hill, United States

Reviewed by:

Baolin Liao,

Guangzhou Medical University, China

Ivan Toplak,

University of Ljubljana, Slovenia

*Correspondence:

Juliet A. Shenge

julietshenge@dui.edu.ng

TORCID:

Juliet $A$. Shenge orcid.org/000-0003-1298-8522

Carla Osiowy

orcid.org/0000-0002-5429-7220

Specialty section

This article was submitted to Viral Disease Investigation,

a section of the journal

Frontiers in Virology

Received: 16 July 2021

Accepted: 22 September 2021

Published: 18 October 2021

Citation:

Shenge JA and Osiowy C (2021)

Rapid Diagnostics for Hepatitis $B$ and

$C$ Viruses in Low- and Middle-Income

Countries. Front. Virol. 1:742722.

doi: 10.3389/fviro.2021.742722

\section{Rapid Diagnostics for Hepatitis B and C Viruses in Low- and Middle-Income Countries}

\author{
Juliet A. Shenge ${ }^{1 * t}$ and Carla Osiowy ${ }^{2 \dagger}$ \\ ${ }^{1}$ Department of Biological Sciences, Dominican University, Ibadan, Nigeria, ${ }^{2}$ Viral Hepatitis and Bloodborne Pathogens \\ Section, National Microbiology Laboratory, Public Health Agency of Canada, Winnipeg, MB, Canada
}

The global health challenge posed by hepatitis B virus (HBV) and hepatitis $\mathrm{C}$ virus $(\mathrm{HCV})$ persists, especially in low-and-middle-income countries (LMICs), where underdiagnosis of these viral infections remains a barrier to the elimination target of 2030. HBV and HCV infections are responsible for most liver-related mortality worldwide. Infected individuals are often unaware of their condition and as a result, continue to transmit these viruses. Although conventional diagnostic tests exist, in LMIC they are largely inaccessible due to high costs or a lack of trained personnel, resulting in poor linkage to care and increased infections. Timely and accurate diagnosis is needed to achieve elimination of hepatitis B and C by the year 2030 as set out by the World Health Organization Global Health Sector Strategy. In this review rapid diagnostic tests allowing for quick and cost-effective screening and diagnosis of HBV and HCV, are discussed, as are their features, including suitability, reliability, and applicability in LMIC, particularly those within Africa.

Keywords: hepatitis B virus, hepatitis C virus, rapid diagnostics, future directions, point-of-care

\section{INTRODUCTION}

Elimination of viral hepatitis by 2030, as articulated in the Global Hepatitis Health Sector Strategy (1), is dependent on several factors, including increased rates of diagnoses in global communities facilitated by use of dried blood spot technology and rapid diagnostic tools, such as point-of-care (POC) assays, to increase access to testing, care and therapy $(2,3)$. Gaps in hepatitis B virus (HBV) and hepatitis $\mathrm{C}$ virus (HCV) screening, treatment, and monitoring, as well as a lack of effective therapeutic management options for HBV/HCV-related liver cancer in resource-poor countries have resulted in a low survival rate in affected individuals (4). Elimination of viral hepatitis, especially hepatitis $B$ and hepatitis $C$, can only become feasible when increased screening, diagnosis and other health care services are made accessible to an infected population often unaware of their infection status (5), or who have not yet entered into care and treatment (6).

Studies have identified numerous barriers to the diagnosis of viral hepatitis in a timely and accurate fashion. Particularly in low- and middle-income countries (LMIC) (7), conventional laboratory-based tests (LBT) may not be accessible, due to a lack of laboratory infrastructure, equipment capacity, or a skilled workforce able to provide diagnostic testing under a quality assurance program (8). Further challenges include socioeconomic inequities precluding some from accessing quality care, or the remoteness of some communities, necessitating shipping of clinical specimens to central laboratories, which can compromise specimen integrity and delay test results. These obstacles limit timely diagnosis of infection, allowing for ongoing transmission in keeping with the observed hyper-endemicity of HBV and HCV infections in LMIC (1). Countries classified 
as LMIC, based on World Bank rankings (9), may also experience unique regional challenges, while a lack of reliable infrastructure and financial resources are common factors (10). Social factors may also be considered to influence HBV and HCV transmission in LMICs. Major challenges facing sub-Saharan African regions include situations in which internally displaced persons may seek safety and migrate as refugees to adjacent countries. In this environment, refugees are normally not screened for viral hepatitis $(11,12)$ nor is vaccination commonly provided (13). These exceptional circumstances disrupt the standard of care required to appropriately screen for and detect infection, leading to underdiagnosis of viral hepatitis and an inadequate system for prevention, contact tracing, and entry into care.

Chronic hepatitis B (CHB) infection affects over a quarter of a billion individuals worldwide, accounting for most chronic viral hepatitis infections in LMIC ( 230 million) (14). Similarly, HCV infections within LMIC account for $73 \%$ of worldwide chronic HCV, or $\sim 52$ million people $(14,15)$. HBV and HCV are among the major bloodborne viruses that infect and replicate in liver cells (hepatocytes), resulting in a high risk of consequent severe disease, including cirrhosis and hepatocellular carcinoma (16). Hepatitis B and C viruses, are transmitted primarily by blood and bodily fluids from infected persons, with average incubation periods of about 30 and 45 days, respectively (17, 18). Sexual transmission and parenteral-associated risk factors, such as injection drug use or unsafe medical practices, are common among both HBV and HCV infections $(18,19)$, while the risk of mother-to-infant transmission is higher with HBV than HCV chronically infected mothers, depending upon viral load and co-infections (20). Within LMIC, vertical transmission of HBV from mother to child is understood to be the major contributor to endemicity (21), although multiple sex partners, occupational percutaneous transmission, and lack of awareness of HBV also contributes to increased prevalence, particularly within sub-Saharan Africa $(12,22,23)$. HCV is transmitted in the same manner, although the major source of HCV endemicity in LMIC is iatrogenic transmission (healthcare exposures, people who inject drugs (PWID), etc.) $(12,24)$. Acute HBV and HCV infections may be associated with mild or severe symptoms, with a variable risk of developing chronic infection, including age at infection for $\operatorname{HBV}(6,25)$. Among HIV/HBV or HIV/HCV co-infected patients, severe hepatic outcomes due to viral hepatitis infection will impact the overall severity and progression of disease $(3,26)$. The prevalence of $\mathrm{HBV}$ and $\mathrm{HCV}$ among sub-Saharan African countries is similar, but will differ depending on the risk level among populations. Studies within Nigeria have reported an HBV prevalence of $7.4 \%(241 / 3,238)$ among pregnant women (27), $10 \%$ among students in tertiary institutions (22), and 5.3\% prevalence among HIV co-infected children (28). The prevalence of anti-HCV seropositivity among Nigerian students aged 21-23 years old was $12 \%$ (24), but was considerably lower in pregnant women $(0.36 \%)$ and blood donors $(1.43 \%)(12,29)$. Ayele et al. (12) reported an overall HBsAg and anti-HCV antibody prevalence of $7.3 \%(33 / 453)$ and $2.0 \%$ (9/453) among refugees in Ethiopia, respectively (12). Medical students in eastern Ethiopia were reported to have an $\mathrm{HBsAg}$ prevalence of $11.5 \%(95 \% \mathrm{CI}=8.6,14.7)$, while blood donors in southern Nigeria had $31.71 \%$ (of 164 cases) HBsAg positivity (30, 31 ). Thus, the epidemiology and unique conditions influencing transmission risk and prevalence of $\mathrm{HBV}$ and $\mathrm{HCV}$ within subSaharan Africa pose challenges for the detection, management, and prevention of viral hepatitis. This review aims to describe various HBV and HCV biomarkers and the rapid diagnostic tools that are available for their detection. The utility of these assays within LMIC, particularly within sub-Saharan Africa, will also be discussed.

\section{SEROLOGICAL AND MOLECULAR MARKERS OF HBV AND HCV INFECTIONS}

Hepatitis B and hepatitis C viral particles are comprised of core-composed capsids and a host lipid envelope studded with viral proteins. Viral particles are secreted from infected cells and can be detected in the blood of patients; thus, these protein components are also a target of the host immune system (32). Infection with HBV produces a host of immune responses in patients with resultant immunological markers detectable in the blood $(33,34)$. These markers (Table 1), function at different levels of screening, diagnosis, assessment of liver disease stage, eligibility for treatment, treatment management, and monitoring for hepatocellular carcinoma (HCC) (32). Different HBV serological markers of infection include the small surface protein ( $\mathrm{HBsAg}$ ), primarily detected in serum and secreted as subviral particles consisting of host lipid and membrane-bound protein, antibody to the surface protein (anti-HBs), antibody to the viral core protein (anti-HBc) consisting of both immunoglobulin $\mathrm{M}(\operatorname{IgM})$ and immunoglobulin $\mathrm{G}(\mathrm{IgG})$, the secreted, non-structural HBeAg protein, and antibody to HBeAg (anti-HBe) (35). HBV DNA present in viral particles can be extracted from patient serum for detection, quantification, and sequence analysis, as a molecular marker. Novel HBV biomarkers are also being explored for their predictive value in patient treatment and management and include $\mathrm{HBV}$ core-related antigen ( $\mathrm{HBcrAg}$ ) and HBV serum RNA $(38,45)$. The whole of the HBV marker profile provides a road map to understand the different phases of HBV infection and thus they are key diagnostic components for screening, diagnosis and treatment management (Table 1).

HCV is initially diagnosed through serology by the use of an enzyme immunoassay (EIA) which typically detects antiHCV in serum or plasma (46). Primary serological results are normally confirmed by an orthogonal immunoassay approach, an immunoassay signal to cutoff ratio or by use of molecular tools such as nucleic acid amplification tests using polymerase chain reaction to detect the HCV RNA $(47,48)$. As a positive antibody test alone cannot differentiate acute from chronic HCV infection (49), laboratory diagnosis of acute HCV infection is aided by observed seroconversion, or a positive test for viral detection (HCV RNA or core antigen; Table 1) in a seropositive case not previously reported, consistent with epidemiological risk and exposure history. 
TABLE 1 | Detectable serological and molecular markers of HBV and HCV infection.

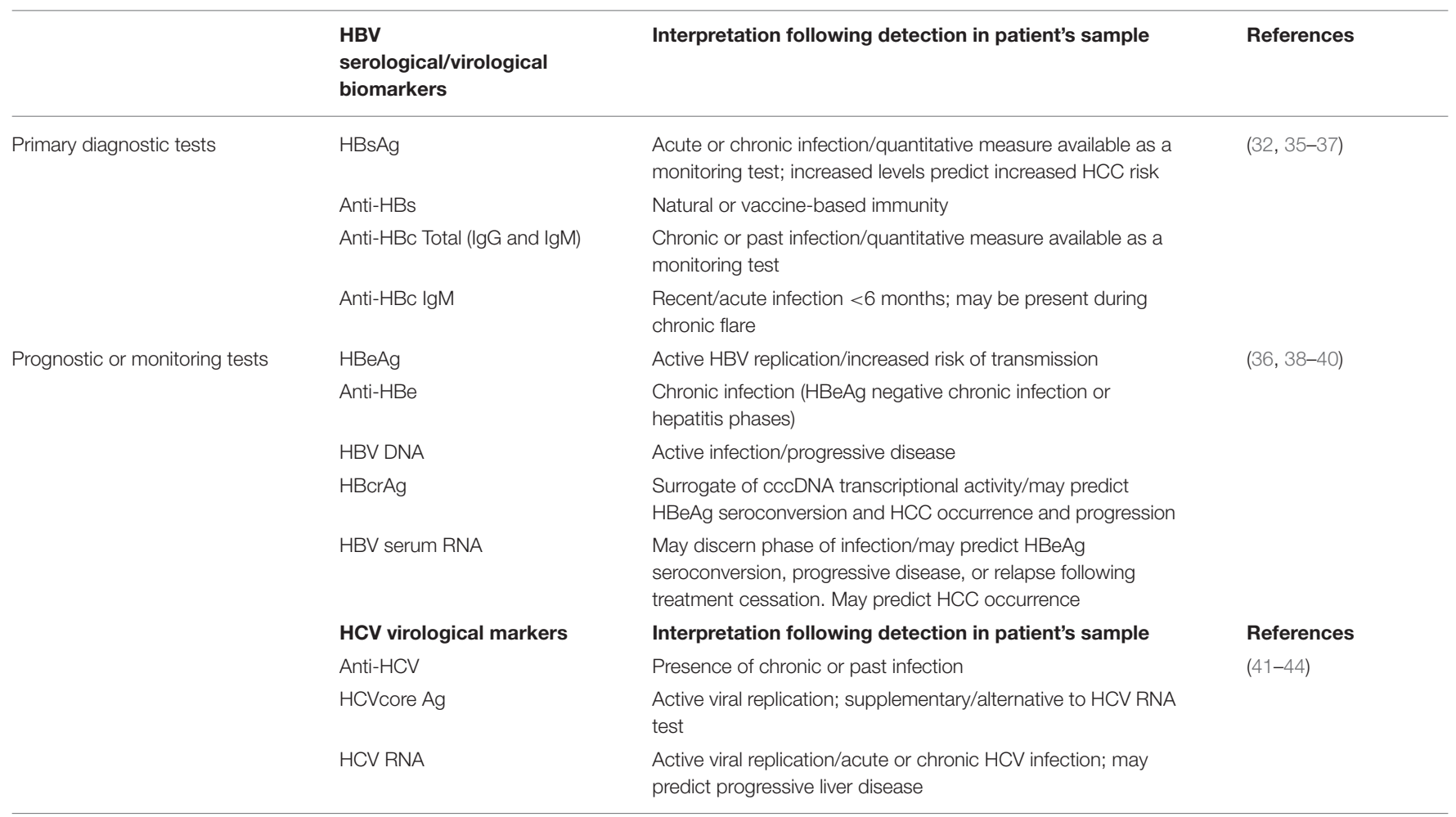

\section{RAPID POINT OF CARE DIAGNOSTIC TESTING}

Diagnoses of HBV and HCV infections have traditionally been performed with conventional serological and molecular LBT to detect relevant serum-based antibodies and antigens as well as extracted viral nucleic acid (Table 1) $(50,51)$. LBT tests have been the gold standard for diagnoses of HIV, HBV and $\mathrm{HCV}$ infections in both resource rich and limited countries (52). Although gold standard EIA and molecular detection tests have exquisitely high sensitivity and specificity, limitations exist regarding their use in resource-limited regions, including inaccessibility, long turn-around time, need for well-trained staff and a well-equipped laboratory, and most importantly high costs (36), which may be overcome by use of less expensive and rapid or POC diagnostic tests which are attractive alternatives to LBT (53). Rapid diagnostic tests may be performed by the user (selftest) or trained personnel in the home or other non-medical facilities. Rapid tests that are performed within health facilities staffed by health professionals are POC tests, which permit rapid diagnosis and treatment or entry into care in a single visit (54). Self-testing strategies which remove the requirement to undergo POC testing at a healthcare facility have been assessed in LMIC regions and have shown advantages of ease of use, convenience, and privacy; however, provision of testing instructions, at the point of sale (pharmacy or hospital) is likely required to minimize confusion and ensure the procedure is followed correctly (55, 56). The major limitations of most POC tests in LMIC involve procurement, distribution and handling of POC tests, training of personnel, and regulatory protocols which may hinder access in certain LMIC (32).

LMIC may benefit from reappraisal of the testing algorithm used in high income countries, such that entry into care and treatment is initiated based on a combination of rapid and confirmatory testing to provide the most efficient, costeffective, and accurate diagnoses (57-60). Significantly, the costeffectiveness and utility of rapid tests for effective screening is not necessarily realized in high resource countries, dependent on infection prevalence and the rate of successful prevention and management of chronic infection (61). Well-recognized testing platforms for rapid diagnostic testing that will be discussed in this review include lateral flow devices (serological marker detection), rapid, cartridge-based molecular marker detection devices, and dried blood spot collection to facilitate screening, diagnosis, and monitoring.

\section{Lateral Flow Rapid Diagnostic Tests (RDT)}

Three HBV immunochromatographic RDT that have been prequalified by the World Health Organization (WHO) include Determine HBsAg (Alere Medical Co. Ltd, Chiba-ken, Japan), VIKIA HBsAg (bioMerieux SA, Marcy-I'E'toile, France) and SD Bioline WB (Abbott Diagnostics Korea Inc. Giheung-gu, Republic of Korea) [74]. These RDTs have met WHO ASSURED criteria (affordable, sensitive, specific, user-friendly, rapid and robust, equipment-free, and deliverable to end-users) and detect HBsAg and HBeAg in a single-use, disposable format (62). Evaluation of a rapid immunochromatographic test (Binax NOW, Maine, USA) for simultaneous detection of HBsAg and 
HBeAg, in comparison with standard EIA, showed excellent accuracy, with sensitivity and specificity for HBsAg detection at 95 and $100 \%$, respectively, although performance characteristics for $\mathrm{HBeAg}$ detection were decreased compared with the EIA method ( $80 \%$ sensitivity, $98 \%$ specificity) (63).

Several immunochromatographic lateral flow RDT have been tested and found suitable for HCV diagnosis. Mahajan et al. (64), compared three different RDT (Alere Trueline; Benesphera HCV Rapid Card test; AccuTest HCV) manufactured in India for detection of HCV antibody. They found moderate sensitivity (range of 65-77\%) and excellent specificity (100\%) with HCV suspected cases within a Delhi liver clinic, with increased sensitivity among RNA positive patients (64). The InTec POC cassette (InTec Products, Inc. Fujian, China) has been evaluated in several HCV screening studies and displays good sensitivity and specificity $(>98 \%)$ for screening general and high-risk populations in Pakistan (65). Sensitivity of HCV RDT among HIV/HCV co-infected populations can be affected by HIV status. Hence, external validation of the RDT is needed prior to testing in such populations (65).

The OraQuick HCV rapid test, developed by OraSure Technologies, is a single-use, non-invasive lateral flow indirect immunoassay approved by the FDA for detection of antibodies to $\mathrm{HCV}$, mostly in oral mucosal transudate (OMT), but also in blood, serum, or plasma, with a comparable sensitivity and specificity to gold standard EIA/chemiluminescent immunoassays $(66,67)$. The sensitivity of the OraQuick HCV rapid test in OMT was found to be $99.1 \%$, while specificity was $100 \%$ (68). For fingerstick blood specimens, the OraQuick assay in comparison to standard LBT EIA venipuncture blood testing, was shown to provide same-day test results, while LBT analysis took almost 3 days (54), which in a real-world setting greatly improves the opportunity to link patients to care and treatment. An important limitation to the OraQuick rapid test, however, is the high cost of the assay, at $\sim \$ 7$ US per test $(66,69)$. The OraQuick HCV test using either whole blood or OMT provided high levels of accurate detection of HCV among PWID and commercial sex workers in sub-Saharan Africa, suggesting an improved screening algorithm for at-risk populations to aid in regional elimination efforts (70). The Well Oral anti-HCV test (Jiangsu Well Biotech Co., Ltd., Jiangsu, China) also screens for antibody to HCV, offers high sensitivity ( $>91 \%)$ and specificity (98\%), and is comparable to the OraQuick HCV assay (98.5\% concordance) (71).

\section{Nucleic-Acid-Based RDT}

The GeneXpert system (Cepheid, Sunnyvale, CA, USA) is a fully automated, self-contained and rapid $(\sim 1-3 \mathrm{~h})$ cartridgebased platform for the detection of pathogen nucleic acid and host gene targets by PCR. Assays are available for a variety of bacterial, parasitic and viral pathogens, including $\mathrm{HBV}$ and $\mathrm{HCV}$, although regulatory approvals are pending for certain countries (72). The GeneXpert system and selfcontained cartridges may be prohibitively expensive in certain resource-limited LMIC as the costs are $\sim \$ 12,000-\$ 64,000$ US for instruments, depending on cartridge module number, and $\sim \$ 15$ US per cartridge for HBV and HCV nucleic acid targets.
However, endemic regions may qualify for a price discount and the GeneXpert platform is already established in many LMIC for tuberculosis and other pathogens, such as HIV and other sexually-transmitted infections (73-76). HBV and HCV cartridges are available for viral load (VL) quantification in serum/plasma or by fingerstick (HCV only) and thus are applicable as a near-patient POC test that would be performed in a healthcare facility for patient management purposes. The manufacturer's performance attributes state excellent detection sensitivity for plasma/serum assays, ranging from 3.2 to 6.1 $\mathrm{IU} / \mathrm{mL}$, dependent on matrix and test, with broad linear ranges (74). The Xpert HCV VL Fingerstick assay provides a result within $60 \mathrm{~min}$ and demonstrates a limit of detection ranging from 22 to $35 \mathrm{IU} / \mathrm{mL}$, dependent upon the HCV genotype (74).

The Xpert HBV VL assay has been evaluated against multiple conventional quantitative nucleic acid platforms, such as the Roche Cobas, and Abbott RealTime HBV assays and has shown very good concordance $(77,78)$. Assessment of the platform within a tertiary care hospital clinic in Addis Ababa, Ethiopia, demonstrated utility of the Xpert HBV VL to identify patients requiring initiation of treatment, with an Xpert cutoff of $4,190 \mathrm{IU} / \mathrm{mL}$ and $35,800 \mathrm{IU} / \mathrm{mL}$ equivalent to $\geq 2,000 \mathrm{IU} / \mathrm{mL}$ and $\geq 20,000 \mathrm{IU} / \mathrm{mL}$, as determined by a high-throughput LBT method (79). A strong positive correlation in quantitative results among most platforms was observed $(74,80-83)$, suggesting the Xpert HBV VL assay is a promising alternate to conventional high throughput platforms for initiating and monitoring of antiviral treatment, although the cost-effectiveness of this would be contingent upon sample throughput.

With the increased affordability and availability of curative pan-genotypic direct-acting antiviral treatment for HCV in lowresource LMIC (84), the need for diagnostic tools to rapidly diagnose infection and monitor treatment is essential to meet the Global Health Sector goals for hepatitis C infection. The Xpert HCV VL assays for serum/plasma or whole capillary blood by fingerstick have been evaluated in comparison to conventional assays which demonstrated accurate quantification, including among various HCV genotypes $(74,83)$. Validation of the Xpert HCV VL test in an Indonesian study suggests that this platform offers advantages for decentralized services throughout resource-limited regions to improve linkages to care and treatment of HCV (85). Several studies involving populations of PWID have shown the practicality of the Xpert HCV VL Fingerstick test to provide nucleic acid diagnosis with $>98 \%$ sensitivity $(73,86)$. Similarly, combining RDT screening, Xpert viral load quantification and portable FibroScan liver elastography, Shiha et al. $(87,88)$, has shown that a single visit diagnosis, assessment and entry into care is possible for HBV and HCV through an Egyptian community-based pilot study. Grebely et al. (89), have proposed an off-label use of the GeneXpert fluorescence output during test runs to allow more rapid detection of HCV RNA positivity (within $30 \mathrm{~min}$ ), although there are important limitations to this (90). Further technology improvements should permit true point-of-care efficiency to reduce the time to diagnosis and allow immediate initiation of treatment and patient management. 


\section{Dried Blood Spot (DBS)/Microsample Specimen Collection}

The use of DBS testing enables mass screening of a population, but with varying levels of specificity and sensitivity (91). DBS is a means of collecting capillary whole blood by a retractable lancet jab to the finger or heel, which is dropped onto blotting paper or an alternate absorbent and dried. Pre-printed circles of set diameter on the blotting paper or cards (such as Whatman ${ }^{\circledR}$ Protein Saver Cards) hold $\sim 75-80 \mu \mathrm{L}$ capillary whole blood per circle (92). The convenience and utility of DBS is illustrated by the ease of storage (at ambient temperature), shipping requirements (depending on the jurisdiction, dried cards are considered non-infectious and so may be shipped by normal post) and utility for both molecular and serological diagnostic tests. Eluted blood from punched spots on DBS cards can be used to diagnose and monitor HBV and HCV infections in remote or resource -limited settings, where storage and shipment facilities for fresh sera may not be available. Jackson et al. (74) evaluated real-world DBS collection in Kiribati, a remote region of the Pacific, for HBV and HDV serological testing. A detection rate of 95.6\% for $\mathrm{HBsAg}$, 81\% for $\mathrm{HBeAg}$, 73.2\%for $\mathrm{HBeAb}$, and $91.6 \%$ for anti-HDV in contrived specimens was observed. In the same study, nucleic acid testing (NAT) was able to detect HBV DNA in 50 of $70(71.4 \%)$ DBS eluates, while HDV RNA was detected in 42 of 47 (89\%) DBS eluates (74). Several studies have shown the reliability of DBS for accurate HBV DNA quantification using either contrived specimens $(83,93)$ or capillary blood specimens collected from patients in regions of Ethiopia and Zambia (74, 94, 95), with subsequent testing by the Xpert HBV Viral Load or standard high throughput quantitative testing platforms. The correlation between DBS and plasma HBV DNA quantification was high $\left(R^{2}=0.92\right)(94)$, mainly at HBV viral loads $\geq 2,000 \mathrm{IU} / \mathrm{mL}$ (95). This evidence supports the use of DBS for rapid, non-invasive collection of diagnostic specimens in LMIC, particularly for treatment monitoring purposes $(83,93)$.

DBS collection and testing was found to provide sensitive and specific detection of HCV antibody by third-generation EIA testing of eluates (91), while the sensitivity of HCV core antigen detection was reduced compared to standard LBT using plasma or serum; however, specificity was high $(91,92)$. HCV RNA quantification from DBS was reported to be lower than LBT viral load tests in chronic HCV patients (96), but quantification values were more accurate with an increase in the number of DBS punched spots used [109]. However, a study by Wlassow et al. (44), in which the Xpert HCV Viral Load assay was used to detect and quantify HCV RNA in DBS whole blood, showed excellent correlation of quantification with serum-based Xpert HCV Viral Load testing and two commercial real-time PCR viral load assays (Abbott RealTime HCV and CAP/CTM HCV v2.0) (44). DBS collection provides options within LMIC or remote areas for confirmatory testing or monitoring of HCV viral load levels, as patients are typically lost to post-screening follow-up requiring a visit to a healthcare facility $(70,97)$.

Other capillary blood collection devices such as the HemaSpot (HemaSpot-HF, Spot on Science, Austin, Texas) cartridge or the Mitra volumetric absorptive microsampler (Neoteryx,
Torrance, CA), respectively, provide the advantage of a precut absorption matrix that equally distributes blood drops during collection or the collection of precise micro-quantities of capillary blood $(98,99)$. As part of a Cambodian HBV serosurvey, Yamamoto et al. (100) investigated HemaSpot capillary blood collection for quantitative measurement of HBsAg by standard high-throughput methods, showing a sensitivity of $92.3 \%$ and a specificity of $100 \%$, although comparison of absolute quantitative values between HemaSpot and serum samples was not assessed (100).

The major limitation with the use of DBS or other absorptive blood collection formats is the lower sensitivity of detection often observed when compared to standard LBT testing of fresh plasma or serum collected by venous puncture (91). Another important limitation is the need for a central or reference laboratory for DBS processing (standardized spot punching and buffered elution). Results may not be obtained within the same day and this can delay linkage to care and treatment of patients (90).

A summary of representative RDT and POC tests within the various platforms described for rapid testing of $\mathrm{HBV}$ and $\mathrm{HCV}$ is found in Table 2.

\section{DISCUSSION}

\section{Utility of HBV and HCV Rapid Diagnostic Tests in LMIC}

Rapid and POC tests have been categorized based on their usefulness in screening and healthcare delivery in LMIC. Numerous studies have reported the specific characteristics, including sensitivity specificity, feasibility, and acceptability of RDT for HBV and HCV screening (101). A systematic review of diagnostic performance and accuracy of seven HCV core antigen assays reported a high sensitivity of $93.4 \%$ and a high specificity (>98\%), when compared with conventional nucleic acid technologies $(113,114)$. A large comparison study by Jargalsikhan (37) investigating the diagnostic accuracy of 19 RDTs produced by different companies (ABON, CTK Biotech, Cypress Diagnostics, Green Gross, Human Diagnostic, Humasis, InTec, OraSure, SD Bioline, Wondfo), evaluated the tests for HBsAg and HCV antibody screening in a Mongolian liver clinic population. Excellent sensitivity and specificity scores of 100 and 99\%, respectively, were obtained for HBsAg detection. However, a lower average sensitivity of $98.9 \%$ and average specificity of $96.7 \%$ were reported for detection of HCV antibody (37). A similar study evaluating seven RDTs for detection of HCV antibodies from different risk populations (blood donors, PWID) among several regions in China, yielded both clinical sensitivity and specificity of $94-100 \%$, with excellent negative predictive value (NPV) (>99.9\%) among the tests evaluated; although differences in HCV genotype detection were observed (53). A cross-sectional study on the prevalence of HBV among pregnant women in Ethiopia utilized an HBsAg RDT to screen women at antenatal clinics. The study showed a prevalence of $5.9 \%$, which was similar to previous findings in other parts of the country and highlighted behavioral risk factors for targeting during prevention efforts (115). A systematic review 
TABLE 2 | HBV and HCV rapid or point of care test performance characteristics and utility for LMIC.

\begin{tabular}{|c|c|c|c|c|c|c|c|c|}
\hline \multirow[b]{2}{*}{ Platform/Technology } & \multicolumn{8}{|c|}{ Range } \\
\hline & Examples & Target & Specimen & $\begin{array}{l}\text { Turn around time } \\
\text { (Min) }\end{array}$ & Sensitivity \% & Specificity \% & $\begin{array}{l}\text { LMIC } \\
\text { Impact/Utility }\end{array}$ & References \\
\hline \multirow[t]{8}{*}{ Lateral flow immuno-assay } & SD Bioline & HBsAg, anti-HCV & $\begin{array}{l}\text { Capillary } \\
\text { blood/serum/plasma }\end{array}$ & 30 & $98.8-100$ & $95.1-100$ & Blood screening, & $(101-103)$ \\
\hline & Alere Determine & $\begin{array}{l}\text { HBsAg, anti-HCV, } \\
\text { anti-HIV }\end{array}$ & Plasma & $30-50$ & $94.1-100$ & $98.1-100$ & $\begin{array}{l}\text { Screening } \\
\text { Diagnosis }\end{array}$ & $(35,104)$ \\
\hline & Chembio DPP & Anti-HCV & Plasma & $15-20$ & $97.9-98.2$ & $97.2-99.2$ & $\begin{array}{l}\text { Management, } \\
\text { Screening }\end{array}$ & $(105)$ \\
\hline & VIKIA & HBsAg & Serum/plasma & 30 & $98.1-100$ & $97.9-100$ & Screening & $(102,106)$ \\
\hline & Medmira Multiplo & $\begin{array}{l}\text { Anti-HCV, anti-HIV, } \\
\text { anti-HBC }\end{array}$ & Blood/serum/plasma & $15-20$ & $96.2-99.1$ & $99.7-100$ & Screening & $(107)$ \\
\hline & One step & $\mathrm{HBsAg}$, anti-HCV & Serum & $<50$ & $94.5-100$ & $92.7-98.3$ & $\begin{array}{l}\text { Screening, } \\
\text { Diagnosis }\end{array}$ & (108) \\
\hline & OraQuick & Anti-HCV & Saliva/serum/plasma & $<40$ & $99.1-100$ & $99.7-100$ & Screening & (68) \\
\hline & Well oral & Anti-HCV & Plasma & 30 & $95.1-97.2$ & $98.3-99.1$ & Screening & (71) \\
\hline \multirow[t]{4}{*}{ Nucleic acid rapid testing } & GeneXpert & $\begin{array}{l}\text { HIV } \\
\text { HBV DNA } \\
\text { HCV RNA, Viral } \\
\text { load }\end{array}$ & Plasma/serum & $30-60$ & $>98$ & $>99$ & $\begin{array}{l}\text { Diagnosis, } \\
\text { Management }\end{array}$ & $(73,79,86)$ \\
\hline & GeneDrive & $\begin{array}{l}\text { HBV DNA, HCV } \\
\text { RNA }\end{array}$ & Plasma/serum & $70-90$ & $>98$ & $>95$ & $\begin{array}{l}\text { Diagnosis, } \\
\text { Management }\end{array}$ & $(109,110)$ \\
\hline & $\begin{array}{l}\text { Molbio } \\
\text { Truenat }\end{array}$ & $\begin{array}{l}\text { HBV DNA } \\
\text { HCV RNA }\end{array}$ & Venous blood & 35 & $>96$ & $>98$ & $\begin{array}{l}\text { Diagnosis, } \\
\text { Management }\end{array}$ & (111) \\
\hline & $\begin{array}{l}\text { Blink DX } \\
\text { Bead-based }\end{array}$ & $\begin{array}{l}\text { HBV DNA, HCV } \\
\text { RNA }\end{array}$ & Venous blood & N/A & N/A & $\mathrm{N} / \mathrm{A}$ & $\begin{array}{l}\text { Diagnosis, } \\
\text { Management, } \\
\text { Research }\end{array}$ & $(89,112)$ \\
\hline \multirow[t]{3}{*}{ DBS/ Microsample specimen collection } & Whatman 3M FTA & $\begin{array}{l}\text { HBsAg, HBeAg, } \\
\text { HBV,HCV,HDV VL }\end{array}$ & $\begin{array}{l}\text { Capillary whole } \\
\text { blood }\end{array}$ & 30 & $89-95.6$ & $89.1-96.1$ & $\begin{array}{l}\text { Remote } \\
\text { monitoring }\end{array}$ & $(74,83,91,93)$ \\
\hline & HemaSpot & qHBsAg & $\begin{array}{l}\text { Whole blood, } \\
\text { serum }\end{array}$ & $5-15$ & 92.3 & 100 & $\begin{array}{l}\text { Sampling, testing, } \\
\text { research }\end{array}$ & (100) \\
\hline & $\begin{array}{l}\text { Neoteryx/Quanterix } \\
\text { Simoa } \\
\text { Mitra }\end{array}$ & $\begin{array}{l}\text { Viral load, proteins, } \\
\text { Digital EIA }\end{array}$ & $\begin{array}{l}\text { Serum, plasma, } \\
\text { DBS, saliva }\end{array}$ & $3-5$ & 98 & 100 & $\begin{array}{l}\text { Diagnosis, remote } \\
\text { monitoring, } \\
\text { Research }\end{array}$ & $\begin{array}{l}\text { www.neoteryx. } \\
\text { com }\end{array}$ \\
\hline
\end{tabular}


and meta-analysis compared 25 commercially available $\mathrm{HBsAg}$ RDT with 15 reference EIA, involving 36,919 samples. Assay sensitivities ranged from 50 to $100 \%$ with an overall pooled sensitivity of $90.0 \%$, while specificities ranged from 69 to $100 \%$, with an overall pooled specificity of $99.5 \%$ (33). Comparison of RDTs with NAT, involving 1710 samples, demonstrated a range of sensitivity from 38 to $99 \%$ with an overall pooled sensitivity of $93.3 \%$. Specificities ranged from 94 to $99 \%$, with an overall pooled specificity of $98.1 \%$ (33). In a field-based study the sensitivity of detecting HBsAg using the Determine HBsAg (Alere) test among HIV-infected patients in Tanzania was 96\% (95\% CI $82.8-99.6 \%$ ), with $100 \%$ specificity (95\% CI, 98.9-100\%) (116), illustrating excellent screening accuracy among a co-infected population. However, in a study involving HIV/HCV co-infected and HCV mono-infected populations from Nigeria, Vetter et al. (105) reported that HIV co-infection impacted the sensitivity of certain HCV antibody detection RDTs (reduced to $<95 \%$ ), although specificity remained high ( $\geq 99 \%)$ for most anti-HCV RDT, regardless of HIV co-infection (105). Thus, it is important that the sensitivity of RDTs is evaluated among individual LMICs and populations, to determine the most appropriate platform/test that meets sensitivity requirements for that population. Most RDTs demonstrate very good specificity, which is an important characteristic for an endemic population, as the test will identify true positives above the limit of detection. The ultimate goal of screening and diagnosis is to link patients to treatment and management of viral infection in order to reduce severe outcomes, including cirrhosis and hepatocellular carcinoma. As there is a lack of accessible options to diagnose liver disease and injury within LMIC (117), timely diagnosis of chronic infection involving RDTs is a means to address the ongoing burden of viral hepatitis within LMIC regions.

There are a number of limitations with RDT. These include lack of access and non-validation of available kits for screening and diagnosis in some regions (118). Low clinical sensitivity has already been described for RDT assays, while healthcare infrastructure and increased costs are associated with molecular POC assays (119). The positive predictive value (PPV) of most RDT will be dependent on the HBV and HCV population prevalence, such that false positive results may frequently occur in low prevalence populations, which may not be a concern in LMIC endemic regions (53). Thus, there are multiple advantages offered by RDT for inexpensive and rapid largescale population screening and diagnosis within endemic regions to allow early diagnosis, patient care and containment of epidemics (120-122). RDT costs within LMIC are relatively inexpensive, ranging from $\sim \$ 1.25$ to $\$ 4.00$ USD per test for Alere Determine, Medmira Multiplo, SD Bioline, One Step, and VIKIA tests (123). Inexpensive ( $\sim$ 1 USD) HBsAg RDTs from Chinese manufacturers are often used in LMIC regions lacking accessibility to tests commonly used in higher resource regions. However, tests supporting testing of complex matrices (OMT) or targets (nucleic acid) are understandably more expensive, including the OraQuick test (\$7 USD per stick) and rapid molecular tests using GeneXpert (\$15 USD per cartridge) and Genedrive instruments ( $\$ 29$ USD per test). Dried blood spot or other absorptive blood collection methods range in cost from pennies for Whatman blotting cards (62 cents USD per card) to $\$ 4$ USD for the Mitra microsampler clamshell to $\sim$ \$12 USD for a HemaSpot cartridge.

An important use and application of RDT in resourcelimited settings is in blood screening for transfusion purposes. Blood transfusion is a major source of infection in areas where inadequate screening facilities exist. Unlike standard testing methods such as EIA and NAT, RDT can usually be performed without electricity or need for standard laboratory equipment (57). A study in Congo evaluated 6 RDT (One Step Hepatitis B surface antigen Test ${ }^{\circledR}$ Strip (Accurate, China), One Step Strip Style HBsAg Rapid Screen Test ${ }^{\circledR}$ (Suzhou Medical Supplies CO., LTD, China), SD Bioline HBsAg WB (Multi SD Standard Diagnostics, INC, Republic of Korea), One Step Hepatitis C Virus Test ${ }^{\circledR}$ Strip (Accurate, China), Hepatitis C Virus Antibody (HCV) Test ${ }^{\circledR}$ Strip (Suzhou Medical Supplies CO., LTD, China), SD BioLine HCV (SD Standard Diagnostics, INC, Republic of Korea) for detection of HBsAg and anti-HCV. The study found a sensitivity and a NPV of $100 \%$ whereas the specificity and PPV ranged from 46 to $98.1 \%$. Among the RDT, SB BioLine HBsAg and HCV tests had excellent performance with $100 \%$ sensitivity, 97.1 and $98.1 \%$ specificity, respectively, 100\% NPV and 96.9 and $93.9 \%$ PPV, respectively $(103,108)$. A similar study in Burkina Faso also yielded good sensitivities (range of 90.8-92.8\%) and excellent specificities (range of 97.3 to $\geq 99.0 \%$ ) indicating usefulness of RDT for HBV mass screening in Burkina Faso (124). RDTs carry certain risks for use in blood screening; those tests having lower sensitivity may yield false negative results, particularly in the presence of low HBsAg or HBV/HCV antibody titres, or mutations within the HBsAg antigenic determinant may also prevent accurate detection of HBV infection $(102,125)$.

\section{Future Directions for RDTs: Toward Viral Hepatitis Elimination}

The Global Hepatitis Health Sector goals of HBV and HCV elimination require knowledge of the regional prevalence and epidemiology of both viruses to implement strategies to mitigate risk factors and reduce transmission. The use of RDTs has been used in Lubumbashi, Democratic Republic of Congo to characterize the prevalence of HBsAg positivity in blood donors (7.9\%), thus highlighting the need to improve transfusion safety (126). Furthermore, RDTs were used to determine the epidemiology and prevalence of anti-HCV positivity in adult clinic patients (1.6\%) in Accra, Ghana, providing an understanding of the primary risk association (history of sexually transmitted infections) and reduced prevalence in older individuals (127). To address viral hepatitis elimination efforts, "micro-elimination" strategies are being evaluated within high prevalence sub-populations to implement a "test and treat" model involving rapid POC tests, with the plan to reach global elimination by targeting and intervening at multiple smaller scales. Thailand has proposed a plan involving screening of all adults $>30$ years old with $\mathrm{HBV}$ and HCV lateral flow assays at primary health centers within Phetchabun province to initiate a "test and treat" model of healthcare (128). Success of this model at the regional level 
will make possible national implementation toward the goal of elimination. Micro-elimination of HCV infection has also been evaluated within sub-regions of Romania. The exercise provided important data on the epidemiology of HCV infection and resulted in cost effective screening and delivery of care (129).

Recently a World Health Organization (WHO) Collaborating Center for Laboratory Strengthening and Diagnostic Technology Evaluation (FIND: Foundation for Innovative New Diagnostics. SARS-CoV-2 Diagnostic Pipeline, 2020), created a hub for product development and delivery partnership during the SARS$\mathrm{CoV}-2$ pandemic to increase access to screening, patient care and reduction in transmission of the virus for LMIC (130). This experience and model can be applied directly to HBV and HCV RDT for screening and diagnoses. For example, the use of immunochromatographic assays has been well-established for HIV diagnosis and includes rapid saliva-based and POC tests for $\mathrm{HIV}, \mathrm{HCV}$, and syphilis screening with comparable results to LBT $(52,131)$. Until recently, POC testing for HBV and HCV has not been used as widely as those for HIV diagnoses (118), although WHO guidelines have recommended affordable alternative tests with comparable clinical sensitivity to replace NAT technologies used for confirmatory HCV testing (132). Hence, leveraging on the existing standard protocols for HIV and malaria RDT as well as the diagnostic infrastructure implemented to support SARSCoV-2 testing in LMIC, should allow uniformity of diagnostic implementation for viral hepatitis and other STBBI infections (85). There is an urgency for reliable, accurate, practical and cost-effective viral hepatitis tests, especially in LMIC, where viral hepatitis services and testing are out of the reach of many with most infected individuals not even aware of their infection, and

\section{REFERENCES}

1. World Health Organization. Global Health Sector Strategy on Viral Hepatitis (2016). Available online at: https://apps.who.int/iris/handle/10665/246177 (accessed March 25, 2021).

2. Revill P, Testoni B, Lorcanini S, Zoulim F. Global strategies are required to cure and eliminate HBV infection. Nat Rev Gastroenterol Hepatol. (2016) 13:239-48. doi: 10.1038/nrgastro.2016.7

3. Easterbrook PJ, Roberts T, Sands A, Peeling R. Diagnosis of viral hepatitis. Curr Opin HIV AIDS. (2017) 12:30214. doi: $10.1097 / \mathrm{COH} .0000000000000370$

4. Ryerson AB, Eheman CR, Altekruse SF, Ward JW, Jemal A, Sherman RL, et al. Annual report to the nation on the status of cancer, 1975-2012, featuring the increasing incidence of liver cancer. Cancer. (2016) 122:131237. doi: $10.1002 / \mathrm{cncr} .29936$

5. Shenge JA, Odaibo GN, Olaleye DO. Genetic diversity of hepatitis C virus among blood donors and patients with clinical hepatitis in Ibadan, Nigeria. Arch Basic Appl Med. (2018) 6:79-85.

6. Stasi C, Silvestri C, Voller F. Update on hepatitis C epidemiology: unaware and untreated infected population could be the key to elimination. SN Compr Clin Med. (2020) 2, 2808-15. doi: 10.1007/s42399-020-00588-3

7. Organisation for Economic Co-operation and Development, (OECD). DAC List of ODA Recipients (2021). Available online at: https://www.oecd.org/ dac/financing-sustainable-development/development-finance-standards/ daclist.htm (accessed May 30, 2021).

8. Easterbrook P, Johnson C, Figueroa C, Baggaley R. HIV and hepatitis testing: global progress, challenges, and future directions. AIDS Rev. (2016) 18:3-14. so continue to be a source of transmission to others as they interact through behavioral means and other modes $(115,133)$.

\section{Conclusions}

To increase access to testing and treatment of viral hepatitis, especially in LMIC, there is an urgent need to embrace new non-invasive sampling and testing technologies that involve the use of capillary blood, oral fluids, self-testing at home and at the community level, use of mobile testing, digital, rapid combination, and multi-disease testing (especially for high risk and co-infected patients) (114). Table 2 summarizes existing and emerging RDTs and their potential applicability to LMICs. Innovative technologies that detect disease markers of viral hepatitis in other easy to obtain bodily fluids, such as sweat, may be developed for future use to understand its role in HBV transmission (134, 135), particularly in tropical areas where high temperatures enhance profuse sweating. Proposals on innovative technologies should be funded by government, and the private and public sectors so as to support research activities and manufacturing of new RTD technologies. Adoption of well-validated RDT, including POC tests, to screen and test LMIC regions with a high burden of viral hepatitis $B$ and $C$, will facilitate diagnosis and enhance monitoring of serological and virological markers of infection. This in turn identifies patients for linkage to treatment and care, assisting in the elimination of viral hepatitis.

\section{AUTHOR CONTRIBUTIONS}

All authors listed have made a substantial, direct and intellectual contribution to the work, and approved it for publication.

9. The World Bank. The World by Income and Region (2021). Available online at: https://datatopics.worldbank.org/world-developmentindicators/the-world-by-income-and-region.html (accessed March 27, 2021)

10. van Zyl C, Badenhorst M, Hanekom S, Heine M. Unravelling 'low-resource settings': a systematic scoping review with qualitative content analysis. BMJ Glob Health. (2021) 6:e005190. doi: 10.1136/bmjgh-2021-005190

11. Olanrewaju FO, Olanrewaju A, Omotoso F, Alabi JO, Amoo E, Loromeke $\mathrm{E}$, et al. Insurgency and the invisible displaced population in Nigeria: a situational analysis. SAGE Open. (2019) 1-12. doi: 10.1177/21582440198 46207

12. Ayele A, Abera D, Hailu M, Birhanu M, Desta K. Prevalence and associated risk factors for hepatitis $\mathrm{B}$ and $\mathrm{C}$ viruses among refugees in Gambella, Ethiopia. BMC Public Health. (2020) 20:721. doi: 10.1186/s12889-020-08893-1

13. Odimayo MS, Adebimpe WO, Jeff-Agboola YA, Oyeyemi OT, Okiei BN, Adejumo OA, et al. Screening, vaccination, and referrals as viral hepatitis elimination triad among internally displaced persons in Edo State, Nigeria. Clin Liver Dis. (2020) 16:218-22. doi: 10.1002/cld.1063

14. Tordrup D, Hutin Y, Stenberg K, Lauer JA, Hutton DW, Toy M, et al. Additional resource needs for viral hepatitis elimination through universal health coverage: projections in 67 low-income and middle-income countries. Lancet Glob Health. (2019) 7:e1180-8. doi: 10.1016/S2214-109X(19)30272-4

15. Spearman CW, Dusheiko GM, Hellard M, Sonderup M. Hepatitis C. Lancet. (2019) 394:1451-66. doi: 10.1016/S0140-6736(19)32320-7

16. Smith DB, Bukh J, Kuiken C, Muerhoff AS, Rice CM, Stapleton JT, et al. Expanded classification of hepatitis $C$ virus into 7 genotypes and 67 subtypes: 
updated criteria and genotype assignment web resource. Hepatology. (2014) 59:318-27. doi: 10.1002/hep.26744

17. Acheson, NH. Fundamentals of Molecular Virology. Hoboken, NJ: Wiley. (2007).

18. Farci P, Shimoda A, Coiana A, Diaz G, Peddis G, Melpolder JC, et al. The outcome of acute hepatitis C predicted by the evolution of the viral quasispecies. Science. (2000) 288:339-44. doi: 10.1126/science.288.5464.339

19. Hu K, Cui W. A highly specific and sensitive hepatitis $C$ virus antigen enzyme immunoassay for one-step diagnosis of viremic hepatitis $\mathrm{C}$ virus infection. Hepatology. (2016) 64:415-24. doi: 10.1002/hep.28663

20. Sarpel D, Kushner T, Carter D, Huisman T, Chiu S, Dieterich D. Mother-to-child transmission of hepatitis B and C virus: Review of the epidemiology and current treatment options. Future Virol. (2018) 13:4352. doi: 10.2217/fvl-2017-0069

21. Franco E, Bagnato B, Marino MG, Meleleo C, Serino L, Zaratti L. Hepatitis B: epidemiology and prevention in developing countries. World J Hepatol. (2012) 4:74-80. doi: 10.4254/wjh.v4.i3.74

22. Chikwendu CI, Obi RK, Amadi ES, Shenge JA, Ogbulie JN. Prevalence of hepatitis B surface antigen among healthy asymptomatic students of a tertiary institution in south eastern, Nigeria. Futo J Series. (2018) 4:255-62.

23. Ahmad AE, Bakari AG, Musa BOP, Mustapha SK, Abdullahi IN, Tahir MI, et al. Distribution of hepatitis B virus-positive individuals in Zaria, Nigeria, according to risk-associated practices. Calabar J Health Sci. (2019) 3:25-30. doi: 10.25259/CJHS_7_2019

24. Obi RK, Shenge JA, Chikwendu CI, Amadi ES, Ogbulie JN. Risk factors and sero-prevalence of hepatitis $C$ virus antibody among undergraduate students of federal university of technology, Owerri. Futo J Series. (2018) 4:326-33.

25. D'souza S, Lau KC, Coffin CS, Patel TR. Molecular mechanisms of viral hepatitis induced hepatocellular carcinoma. World J Gastroenterol. (2020) 26:5759-83. doi: 10.3748/wjg.v26.i38.5759

26. Shenge JA, Odaibo GN, Olaleye DO. Phylogenetic analysis of hepatitis C virus among HIV/HCV co-infected patients in Nigeria. PLoS ONE. (2019) 14:e0210724. doi: 10.1371/journal.pone.0210724

27. Magaji FA, Okolo MO, Hassan Z, Shambe IH, Pam VC, Ocheke AN, et al. Prevalence of hepatitis B virus infection among pregnant women in Jos, Nigeria. Ann Afr Med. (2020) 19:176-181. doi: 10.4103/aam.aam_20_19

28. Lawal MA, Adeniyi OF, Akintan PE, Salako AO, Omotosho OS, Temiye EO. Prevalence of and risk factors for hepatitis $\mathrm{B}$ and $\mathrm{C}$ viral coinfections in HIV infected children in Lagos, Nigeria. PLoS One. (2020) 15:e243656. doi: 10.1371/journal.pone.0243656

29. Hilda AE, Kola OJ, Kolawole OE. Prevalence of anti-hepatitis C virus antibody among pregnant women and blood donors at Bowen University teaching hospital, Ogbomoso, Oyo State, Nigeria. J Immunoassay Immunochem. (2017) 38:221-34. doi: 10.1080/15321819.2016.1241264

30. Okoroiwu HU, Asemota EA. Blood donors deferral prevalence and causes in a tertiary health care hospital, southern Nigeria. BMC Health Serv Res. (2019) 19:510. doi: 10.1186/s12913-019-4352-2

31. Tesfa T, Hawulte B, Tolera A, Abate D. Hepatitis B virus infection and associated risk factors among medical students in eastern Ethiopia. PLoS One. (2021) 16:e0247267. doi: 10.1371/journal.pone.0247267

32. Xiao Y, Thompson AJ, Howell J. Point-of-care tests for hepatitis B: an overview. Cells. (2020) 9:2233. doi: 10.3390/cells9102233

33. Amini A, Varsaneux O, Kelly H, Tang W, Chen W, Boeras DI, et al. Diagnostic accuracy of tests to detect hepatitis B surface antigen: a systematic review of the literature and meta-analysis. BMC Infect Dis. (2017) 17:698. doi: 10.1186/s12879-017-2772-3

34. Bertoletti A, Kennedy PT. The immune tolerant phase of chronic HBV infection: new perspectives on an old concept. Cell Mol Immunol. (2015) 12:258-63. doi: 10.1038/cmi.2014.79

35. Evans AA, Cohen C, Block TM. Hepatitis viruses: Hepatitis B and Hepatitis D. In: Kaslow RA, Le Duc JW, Stanberry LR, editors. Viral Infections of Humans: Epidemiology and Control, 4th ed. New York: Springer (2014). p. 747-64. doi: 10.1007/978-1-4899-7448-8_32

36. Gani AW, Wei W, Shi R, Ng E, Nguyen M, Chua M, et al. An automated, quantitative, and multiplexed assay suitable for point-of-care hepatitis $B$ virus diagnostics. Sci Rep. (2019) 9:15615. doi: 10.1038/s41598-019-52147-z

37. Jargalsaikhan G, Eichner M, Boldbaatar D, Bat-Ulzii P, Lkhagva-Ochir O, Oidovsambuu $\mathrm{O}$, et al. Sensitivity and specificity of commercially available rapid diagnostic tests for viral hepatitis B and C screening in serum samples. PLoS One. (2020) 15:e235036. doi: 10.1371/journal.pone.0235036

38. Charre C, Levrero M, Zoulim F, Scholtès C. Non-invasive biomarkers for chronic hepatitis B virus infection management. Antiviral Res. (2019) 169:104553. doi: 10.1016/j.antiviral.2019.104553

39. Kao J. Diagnosis of hepatitis B virus infection through serological and virological markers. Expert Rev Gastroenterol Hepatol. (2008) 2:55362. doi: $10.1586 / 17474124.2 .4 .553$

40. Carey I, Gersch J, Wang B, Moigboi C, Kuhns M, Cloherty G, et al. Pregenomic HBV RNA and hepatitis B core-related antigen predict outcomes in hepatitis B e antigen-negative chronic hepatitis B patients suppressed on nucleos(t)ide analogue therapy. Hepatology. (2020) 72:4257. doi: 10.1002/hep. 31026

41. Busch MP, Shafer KAP. Acute-phase hepatitis C virus infection: Implications for research, diagnosis, and treatment. Clin Infect Dis. (2005) 40:95961. doi: $10.1086 / 428583$

42. Gaudy C, Thevenas C, Tichet J, Mariotte N, Goudeau A, Dubois F. Usefulness of the hepatitis $\mathrm{C}$ virus core antigen assay for screening of a population undergoing routine medical checkup. J Clin Microbiol. (2005) 43:17226. doi: 10.1128/JCM.43.4.1722-1726.2005

43. Hongjaisee S, Doungjinda N, Khamduang W, Carraway TS, Wipasa J, Debes JD, et al. Rapid visual detection of hepatitis C virus using a reverse transcription loop-mediated isothermal amplification assay. Int $\mathrm{J}$ Infect Dis. (2021) 102:440-5. doi: 10.1016/j.ijid.2020.10.082

44. Wlassow M, Poiteau L, Roudot-Thoraval F, Rosa I, Soulier A, Hézode C, et al. The new Xpert HCV viral load real-time PCR assay accurately quantifies hepatitis C virus RNA in serum and whole-blood specimens. J Clin Virol. (2019) 117:80-4. doi: 10.1016/j.jcv.2019.06.007

45. Jiang B, Su R, Ren D, Zheng X, Cao Y, Mi Y, et al. Evaluation of HBV serological markers in treatment-naïv HBV mono-infected patients and HBV-HIV co-infected patients. Virus Res. (2020) 290:198117. doi: 10.1016/j.virusres.2020.198117

46. FDA. Pre-Market Approval: ORAQUICK HCV Rapid Antibody Test. (2021). Available online at: https://www.accessdata.fda.gov/ scripts/cdrh/cfdocs/cfpma/pma.cfm?ID=P080027 (accessed May 29, 2021).

47. FDA. FDA Approves First Treatment for All Genotypes of Hepatitis $C$ in Pediatric Patients (2019). Available online at: https://www.fda.gov/newsevents/press-announcements/fda-approves-first-treatment-all-genotypeshepatitis-c-pediatric-patients (accessed May 29, 2021).

48. Gupta E, Bajpai M, Choudhary A. Hepatitis C virus: screening, diagnosis, and interpretation of laboratory assays. Asian J Transfus Sci. (2014) 8:1925. doi: 10.4103/0973-6247.126683

49. Chung RT. Acute hepatitis C virus infection. Clin Infect Dis. (2005) 41(Suppl. 1):14. doi: $10.1086 / 429490$

50. Irshad M, Mankotia DS, Irshad K. An insight into the diagnosis and pathogenesis of hepatitis C virus infection. World J Gastroenterol. (2013) 19:7896-909. doi: 10.3748/wjg.v19.i44.7896

51. AIDS.gov. FDA Approves First Genotyping Test for Patients With Hepatitis C Virus. (2013). Available online at: https://www.hiv.gov/blog/fda-approvesfirst-genotyping-test-for-patients-with-hepatitis-c-virus (accessed March 26, 2021).

52. Tucker JD, Bien CH, Peeling RW. Point-of-care testing for sexually transmitted infections: recent advances and implications for disease control. Curr Opin Infect Dis. (2013) 26:73-9. doi: 10.1097/QCO.0b013e32835c21b0

53. Chen B, Ma Z, Xu B, Chang H, He X, Pei L, et al. Evaluation of seven rapid diagnostic tests for detection of hepatitis $\mathrm{C}$ virus antibodies in China. J Viral Hepat. (2021) 28:657-63. doi: 10.1111/jvh.13466

54. Assoumou SA, Paniagua SM, Linas BP, Wang J, Samet JH, Hall J, et al. Rapid versus laboratory-based testing for HIV and hepatitis C at a drug detoxification treatment center: a randomized trial. J Infect Dis. (2020) 222:S376-83. doi: 10.1093/infdis/jiaa162

55. Majam M, Fischer A, Reipold EI, Rhagnath N, Msolomba V, Lalla-Edward ST. A lay-user assessment of hepatitis C virus self-testing device usability and interpretation in Johannesburg, South Africa. Diagnostics. (2021) 11:463. doi: 10.3390/diagnostics11030463

56. Reipold EI, Farahat A, Elbeeh A, Soliman R, Aza EB, Jamil MS, et al. Usability and acceptability of self-testing for hepatitis $\mathrm{C}$ virus infection among the 
general population in the Nile delta region of Egypt. BMC Public Health. (2021) 21:1188. doi: 10.1186/s12889-021-11169-x

57. Pruett $C R$, Vermeulen $M$, Zacharias P, Ingram C, Tayou Tagny C, Bloch EM. The use of rapid diagnostic tests for transfusion infectious screening in Africa: a literature review. Transfus Med Rev. (2015) 29:354. doi: 10.1016/j.tmrv.2014.09.003

58. Dinnes J, Deeks JJ, Adriano A, Berhane S, Davenport C, Dittrich $\mathrm{S}$, et al. Rapid, point-of-care antigen and molecular-based tests for diagnosis of SARS-CoV-2 infection. Cochrane Database Syst Rev. (2020) 8:CD013705. doi: 10.1002/14651858.CD013705

59. Chugh Y, Premkumar M, Grover GS, Dhiman RK, Teerawattananon Y, Prinja S. Cost-effectiveness and budget impact analysis of facility-based screening and treatment of hepatitis C in Punjab state of India. BMJ Open. (2021) 11:e042280. doi: 10.1136/bmjopen-2020-042280

60. Bierhoff M, Angkurawaranon C, Rijken MJ, Sriprawa K, Kobphan P, Nosten $\mathrm{FN}$, et al. Tenofovir disoproxil fumarate in pregnancy for prevention of mother to child transmission of hepatitis B in a rural setting on the ThailandMyanmar border: a cost-effectiveness analysis. BMC Pregnancy Childbirth. (2021) 21:157. doi: 10.1186/s12884-021-03612-z

61. Wentworth JJ, Øvrehus ALH, Hansen JF, Biesenbach P, Christensen $\mathrm{PB}$. Emergency department testing is feasible but ineffective to eliminate hepatitis C in Denmark. Infect Dis. (2021). 1-12. doi: $10.1080 / 23744235.2021 .1962542$

62. Dembele B, Affi-Aboli R, Kabran M, Sevede D, Goha V, Adiko AC, et al. Evaluation of four rapid tests for detection of hepatitis B surface antigen in Ivory Coast. J Immunol Res. (2020) 2020:6315718. doi: 10.1155/2020/6315718

63. Lau DT, Ma H, Lemon SM, Doo E, Ghany MG, Miskovsky E, et al. A rapid immunochromatographic assay for hepatitis B virus screening. J Viral Hepat. (2003) 10:331-4. doi: 10.1046/j.1365-2893.2003.00418.x

64. Mahajan S, Agarwal R, Rawat V, Kumar G, Sharma MK, Gupta E. Comparative evaluation of three rapid immunochromatographic test assays with chemiluminescent microparticle immunoassay for the detection of hepatitis C virus antibody. Virus Dis. (2019) 30:3739. doi: 10.1007/s13337-019-00542-5

65. Waheed Y, Najmi MH, Aziz H, Khalid S, Waheed H, Imran M, et al. Evaluation of three rapid screening tests for detection of hepatitis C antibodies on mass scale. Crit Rev Eukaryot Gene Expr. (2019) 29:258. doi: 10.1615/CritRevEukaryotGeneExpr.2018025062

66. Carvalho-Gomes Â, Cubells A, Pallarés C, Hontangas V, Conde I, Di Maira $\mathrm{T}$, et al. A population-based screening for hepatitis $\mathrm{C}$ antibodies and active infection using a point-of-care test in a low prevalence area. PLoS One. (2020) 15:e0228351. doi: 10.1371/journal.pone.0228351

67. Drobnik A, Judd C, Banach D, Egger J, Konty K, Rude E. Public health implications of rapid hepatitis $\mathrm{C}$ screening with an oral swab for communitybased organizations serving high-risk populations. Am J Public Health. (2011) 101:2151-5. doi: 10.2105/AJPH.2011.300251

68. Pallarés C, Carvalho-Gomes Â, Hontangas V, Conde I, Di Maira T, Aguilera $\mathrm{V}$, et al. Performance of the OraQuick hepatitis $\mathrm{C}$ virus antibody test in oral fluid and fingerstick blood before and after treatment-induced viral clearance. J Clin Virol. (2018) 102:77-83. doi: 10.1016/j.jcv.2018.02.016

69. Unicef Supply Division. OraQuick HCV Rapid Antibody Test Kit 25 (2018). Available online at: https://supply.unicef.org/all-materials.html (accessed September 1, 2021)

70. Prabdial-Sing N, Gaelejwe L, Makhathini L, Thaver J, Manamela MJ, Malfeld $\mathrm{S}$, et al. The performance of hepatitis $\mathrm{C}$ virus (HCV) antibody point-of-care tests on oral fluid or whole blood and dried blood spot testing for HCV serology and viral load among individuals at higher risk for HCV in South Africa. Health Sci Rep. (2021) 4:e229. doi: 10.1002/hsr2.229

71. Liu L, Zhang M, Hang L, Kong F, Yan H, Zhang Y, et al. Evaluation of a new point-of-care oral anti-HCV test for screening of hepatitis $\mathrm{C}$ virus infection. Virol J. (2020) 17:14. doi: 10.1186/s12985-020-1293-7

72. Stern AD. Innovation under regulatory uncertainty: evidence from medical technology. J Public Econ. (2017) 145:181200. doi: 10.1016/j.jpubeco.2016.11.010

73. Mohamed Z, Mbwambo J, Rwegasha J, Mgina N, Doulla B, Mwakale P, et al. In-field evaluation of Xpert $\AA$ HCV viral load fingerstick assay in people who inject drugs in Tanzania. Liver Int. (2020) 40:514-21. doi: 10.1111/liv. 14315

74. Jackson K, Holgate T, Tekoaua R, Nicholson S, Littlejohn M, Locarnini S. Evaluation of dried blood spots for hepatitis B and D serology and nucleic acid testing. J Med Virol. (2019) 92:833-40. doi: 10.1002/jmv.25485

75. De Baetselier I, Vuylsteke B, Yaya I, Dagnra A, Diandé S, Mensah E, et al. To pool or not to pool samples for sexually transmitted infections detection in men who have sex with men? An evaluation of a new pooling method using the GeneXpert instrument in West Africa. Sex Transm Dis. (2020) 47:556-61. doi: 10.1097/OLQ.0000000000001191

76. Zidovec Lepej S, Poljak M. Portable molecular diagnostic instruments in microbiology: current status. Clin Microbiol Infect. (2020) 26:41120. doi: 10.1016/j.cmi.2019.09.017

77. Marcuccilli F, Chevaliez S, Muller T, Colagrossi L, Abbondanza G, Beyser $\mathrm{K}$, et al. Multicenter evaluation of the Cepheid Xpert $\AA$ HBV viral load test. Diagnostics. (2021) 11:297. doi: 10.3390/diagnostics11020297

78. Gupta E, Khodare A, Rani N, Singh G, Aggarwal K, Sharma M. Performance evaluation of Xpert HBV viral load (VL) assay: pointof-care molecular test to strengthen and decentralize management of chronic hepatitis B (CHB) infection. J Virol Meth. (2021) 290:114063. doi: 10.1016/j.jviromet.2021.114063

79. Woldemedihn GM, Rueegg CS, Desalegn H, Aberra H, Berhe $\mathrm{N}$, Johannessen A. Validity of a point-of-care viral load test for hepatitis B in a low-income setting. J Virol Methods. (2021) 289:114057. doi: 10.1016/j.jviromet.2020.114057

80. Maasoumy B, Geretti A, Frontzek A, Austin H, Aretzweiler G, Garcia-Álvarez M, et al. HBV-RNA co-amplification may influence HBV DNA viral load determination. Hepatol Commun. (2020) 4:983-97. doi: 10.1002/hep4.1520

81. Abravanel F, Lhomme S, Trémeaux P, Migueres M, Harter A, Haslé C, et al. Performance of the Xpert HBV viral load assay versus the Aptima quant assay for quantifying hepatitis B virus DNA. Diagn Microbiol Infect Dis. (2020) 96:114946. doi: 10.1016/j.diagmicrobio.2019.114946

82. Auzin AM, Slavenburg S, Peters C, Boland G, Rahamat-Langendoen J, Melchers WJG, et al. Rapid, random-access, and quantification of hepatitis B virus using the Cepheid Xpert HBV viral load assay. J Med Virol. (2021) 93:3999-4003. doi: 10.1002/jmv.26392

83. Poiteau L, Wlassow M, Hézode C, Pawlotsky J, Chevaliez S. Evaluation of the Xpert HBV viral load for hepatitis B virus molecular testing. J Clin Virol. (2020) 129:104481. doi: 10.1016/j.jcv.2020.104481

84. World Health Organization. Updated Recommendations on First-Line and Second-Line Antiretroviral Regimens and Post-Exposure Prophylaxis and Recommendations on Early Infant Diagnosis of HIV: Interim Guidelines: Supplement to the 2016 Consolidated Guidelines on the Use of Antiretroviral Drugs for Treating and Preventing HIV Infection. (2018). Available online at: https://apps.who.int/iris/handle/10665/277395 (accessed March 26, 2021).

85. Thedja MD, Wibowo DP, El-Khobar KE, Ie SI, Setiawan L, Murti IS, et al. Improving linkage to care of hepatitis C: Clinical validation of GeneXpert $\AA$ HCV viral load point-of-care assay in Indonesia. Am J Trop Med Hyg. (2021) 105:117-24. doi: 10.4269/ajtmh.20-1588

86. Saludes V, Antuori A, Lazarus JV, Folch C, González-Gómez S, González $\mathrm{N}$, et al. Evaluation of the Xpert HCV VL fingerstick point-of-care assay and dried blood spot HCV-RNA testing as simplified diagnostic strategies among people who inject drugs in Catalonia, Spain. Int J Drug Policy. (2020) 80:102734. doi: 10.1016/j.drugpo.2020.102734

87. Shiha G, Soliman R, Serwah A, Mikhail NNH, Asselah T, Easterbrook P. A same day 'test and treat' model for chronic HCV and HBV infection: Results from two community-based pilot studies in Egypt. J Viral Hepat. (2020) 27:593-601. doi: 10.1111/jvh.13268

88. Shiha G, Soliman R, Mikhail NNH, Easterbrook P. An educate, test and treat model towards elimination of hepatitis $\mathrm{C}$ infection in Egypt: feasibility and effectiveness in 73 villages. J Hepatol. (2020) 72:65869. doi: 10.1016/j.jhep.2019.11.004

89. Grebely J, Catlett B, Jayasinghe I, Valerio H, Hajarizadeh B, Verich A, et al. Time to detection of hepatitis $\mathrm{C}$ virus infection with the Xpert $\mathrm{HCV}$ viral load fingerstick point-of-care assay: facilitating a more rapid time to diagnosis. J Infect Dis. (2020) 221:2043-9. doi: 10.1093/infdis/jiaa037 
90. Grebely J, Applegate TL, Cunningham P, Feld JJ. Hepatitis C point-of-care diagnostics: in search of a single visit diagnosis. Expert Rev Mol Diagn. (2017) 17:1109-15. doi: 10.1080/14737159.2017.1400385

91. Chevaliez S. Strategies for the improvement of HCV testing and diagnosis. Expert Rev Anti Infect Ther. (2019) 17:3417. doi: 10.1080/14787210.2019.1604221

92. Tuaillon E, Kania D, Pisoni A, Bollore K, Taieb F, Ontsira Ngoyi $\mathrm{EN}$, et al. Dried blood spot tests for the diagnosis and therapeutic monitoring of HIV and viral hepatitis B and C. Front Microbiol. (2020) 11:373. doi: 10.3389/fmicb.2020.00373

93. Bargain P, Heslan C, Thibault V, Pronier C. Combined use of dried blood spot and rapid molecular systems: a robust solution to monitor hepatitis B virus infection with potential for resource-limited countries. J Virol Methods. (2020) 283:113908. doi: 10.1016/j.jviromet.2020.113908

94. Stene-Johansen K, Yaqoob N, Overbo J, Aberra H, Desalegn H, Berhe $\mathrm{N}$, et al. Dry blood spots a reliable method for measurement of hepatitis B viral load in resource-limited settings. PLoS One. (2016) 11:e0166201. doi: 10.1371/journal.pone.0166201

95. Vinikoor MJ, Zürcher S, Musukuma K, Kachuwaire O, Rauch A, Chi BH, et al. Hepatitis B viral load in dried blood spots: a validation study in Zambia. J Clin Virol. (2015) 72:20-4. doi: 10.1016/j.jcv.2015.08.019

96. Lange B, Roberts T, Cohn J, Greenman J, Camp J, Ishizaki A, et al. Diagnostic accuracy of detection and quantification of HBV-DNA and HCV-RNA using dried blood spot (DBS) samples - a systematic review and meta-analysis. BMC Infect Dis. (2017) 17:693. doi: 10.1186/s12879-017-2776-z

97. Vázquez-Morón S, Ardizone Jiménez B, Jiménez-Sousa MA, Bellón JM, Ryan P, Resino S. Evaluation of the diagnostic accuracy of laboratory-based screening for hepatitis $\mathrm{C}$ in dried blood spot samples: a systematic review and meta-analysis. Sci Rep. (2019) 9:7316. doi: 10.1038/s41598-019-41139-8

98. Wang J, Li D, Zhou Q, Wiltse A, Zand MS. Antibody mediated immunity to SARS-CoV-2 and human coronaviruses: multiplex beads assay and volumetric absorptive microsampling to generate immune repertoire cartography. Front Immunol. (2021) 12:696370. doi: 10.3389/fimmu.2021.696370

99. Solheim SA, Ringsted TK, Nordsborg NB, Dehnes Y, Levernæs MCS, Mørkeberg J. No pain, just gain: painless, easy, and fast dried blood spot collection from fingertip and upper arm in doping control. Drug Testing Anal. (2021) 11:847-58. doi: 10.1002/dta.3135

100. Yamamoto C, Nagashima S, Isomura M, Ko K, Chuon C, Akita T, et al. Evaluation of the efficiency of dried blood spot-based measurement of hepatitis B and hepatitis C virus seromarkers. Sci Rep. (2020) 10:3857. doi: 10.1038/s41598-020-60703-1

101. Duracinsky M, Thonon F, Bun S, Ben Nasr I, Dara AF, Lakhdari S, et al. Good acceptability of HIV, HBV, and HCV screening during immigration medical check-up amongst migrants in France in the STRADA study. PLoS One. (2020) 15:e0235260. doi: 10.1371/journal.pone. 0235260

102. Chevaliez S, Roudot-Thoraval F, Hézode C, Pawlotsky J, Njouom R. Performance of rapid diagnostic tests for hepatitis B surface antigen detection in serum or plasma. Diagn Microbiol Infect Dis. (2021) 100:115353. doi: 10.1016/j.diagmicrobio.2021.115353

103. Sun C, Iwamoto M, Calzia A, Sreng B, Yann S, Pin S, et al. Demonstration of the diagnostic agreement of capillary and venous blood samples, using hepatitis-C virus SD Bioline( rapid test: a clinic-based study. J Clin Virol. (2019) 111:39-41. doi: 10.1016/j.jcv.2018.12.008

104. Mwenda R, Fong Y, Magombo T, Saka E, Midiani D, Mwase C, et al. Significant patient impact observed upon implementation of point-of-care early infant diagnosis technologies in an observational study in Malawi. Clin Infect Dis. (2018) 67:701-7. doi: 10.1093/cid/ciy169

105. Vetter BN, Reipold EI, Ongarello S, Audu R, Ige FA, Alkhazashvili M, et al. Sensitivity and specificity of rapid diagnostic tests for hepatitis $\mathrm{C}$ virus with or without HIV coinfection: a multicentre laboratory evaluation study. J Infect Dis. (2020) jiaa389. doi: 10.1093/infdis/jiaa389

106. Bottero J, Boyd A, Gozlan J, Lemoine M, Carrat F, Collignon A, et al. Performance of rapid tests for detection of HBsAg and anti-HBsAb in a large cohort, France. J Hepatol. (2013) 58:473-8. doi: 10.1016/j.jhep.2012.11.016

107. Chosewood LC, Wilson DE. Biosafety in Microbiological Biomedical Laboratories. Washington, DC: U.S. Dept. of Health and Human Services,
Public Health Service, Centers for Disease Control and Prevention, National Institutes of Health (2009).

108. Kabamba AT, Mwamba CM, Dessilly G, Dufrasne F, Kabamba BM, Longanga AO. Evaluation of the analytical performance of six rapid diagnostic tests for the detection of viral hepatitis $\mathrm{B}$ and $\mathrm{C}$ in Lubumbashi, Democratic Republic of Congo. J Virol Methods. (2020) 285:113961. doi: 10.1016/j.jviromet.2020.113961

109. Llibre A, Shimakawa Y, Mottez E, Ainsworth S, Buivan T, Firth R, et al. Development and clinical validation of the Genedrive point-of-care test for qualitative detection of hepatitis C virus. Gut. (2018) 67:201724. doi: 10.1136/gutjnl-2017-315783

110. Padhi A, Gupta E, Singh G, Agarwal R, Sharma MK, Sarin SK. Evaluation of the point of care molecular diagnostic Genedrive HCV ID kit for the detection of HCV RNA in clinical samples. Epidemiol Infect. (2020) 123. doi: 10.1101/2020.05.10.20097576

111. Fryer JFA, Heath DE, Wilkinson PD. Minor, World Health Organization Biologicals Unit, WHO Expert Committee on Biological Standardization. (2011) Collaborative Study to Evaluate the Proposed 3rd WHO International Standards for Hepatitis B Virus (HBV) for Nucleic Acid Amplification Technology (NAT)-Based Assays. Available online at: https://apps.who.int/ iris/handle/10665/70779 (accessed March 26, 2021).

112. Sharma S, Pardasani D, Dash PK, Parida M, Dubey DK. Development of magnetic bead based sample extraction coupled polymerase spiral reaction for rapid on-site detection of Chikungunya virus. Sci Rep. (2020) 10:11651. doi: 10.1038/s41598-020-68469-2

113. Freiman JM, Tran TM, Schumacher SG, White LF, Ongarello S, Cohn J, et al. Hepatitis C core antigen testing for diagnosis of hepatitis C virus infection: a systematic review and meta-analysis. Ann Intern Med. (2016) 165:345-55. doi: 10.7326/M16-0065

114. Peeling RW, Boeras DI, Marinucci F, Easterbrook P. The future of viral hepatitis testing: innovations in testing technologies and approaches. BMC Infect Dis. (2017) 17:699. doi: 10.1186/s12879-017-2775-0

115. Asaye Z, Aferu T, Asefa A, Feyissa D, Regasa T, Kebede O, et al. Prevalence of hepatitis $\mathrm{B}$ virus among pregnant women on antenatal care followup at Mizan-Tepi university teaching hospital and Mizan health center, southwest Ethiopia. Int J Gen Med. (2021) 14:195-200. doi: 10.2147/IJGM. S292070

116. Franzeck FC, Ngwale R, Msongole B, Hamisi M, Abdul O, Henning $\mathrm{L}$, et al. Viral hepatitis and rapid diagnostic test based screening for HBsAg in HIV-infected patients in rural Tanzania. PLoS One. (2013) 8:e58468. doi: 10.1371/journal.pone.0058468

117. Moed S, Zaman MH. Towards better diagnostic tools for liver injury in low-income and middle-income countries. BMJ Glob Health. (2019) 4:e001704. doi: 10.1136/bmjgh-2019-001704

118. World Health Organization. Improving the Quality of HIV-Related Point-ofCare Testing: Ensuring the Reliability and Accuracy of Test Results (2021). Available online at: https://apps.who.int/iris/handle/10665/199799 (accessed May 30, 2021).

119. Kozel TR, Burnham-Marusich AR. Point-of-care testing for infectious diseases: past, present, and future. J Clin Microbiol. (2017) 55:231320. doi: 10.1128/JCM.00476-17

120. Urdea M, Penny LA, Olmsted SS, Giovanni MY, Kaspar P, Shepherd A, et al. Requirements for high impact diagnostics in the developing world. Nature. (2006) 444:73-9. doi: 10.1038/nature05448

121. World Health Organization. Infection Prevention and Control During Health Care When Coronavirus Disease (?COVID-19)? is Suspected or Confirmed (2021). Available online at: https://www.who.int/publications/i/item/WHO2019-nCoV-IPC-2021.1 (accessed March 27, 2021).

122. Nouvellet P, Garske T, Mills HL, Nedjati-Gilani G, Hinsley W, Blake IM, et al. The role of rapid diagnostics in managing Ebola epidemics. Nature. (2015) 528:109. doi: 10.1038/nature16041

123. Unicef. Unicef Supply Catalogue_All Products (2018). Available online at: https://supply.unicef.org/all-materials.html (accessed September 1, 2021).

124. Sanou AM, Toyé R, Kagoné T, Nikiéma A, Testa J, Sakandé J, et al. Analytical performance of eight rapid point-of-care tests routinely used for the detection of HBsAg in Burkina Faso: a cross-sectional study. J Clin Virol. (2020) 129:104546. doi: 10.1016/j.jcv.2020.104546 
125. Orlien SMS, Ahmed TA, Ismael NY, Berhe Belay N, Kran AB, Gundersen SG, et al. Field performance of $\mathrm{HBsAg}$ rapid diagnostic tests in rural Ethiopia. J Virol Methods. (2021) 289:114061. doi: 10.1016/j.jviromet.2020.11 4061

126. Kabamba AT, Kalunga BT, Mwamba CM, Nyembo CM, Dufrasne F, Dessilly G, et al. Epidemiological aspects and molecular characterization of the hepatitis B virus among blood donors in Lubumbashi, Democratic Republic of Congo. Transfus Clin Biol. (2021) 28:30-7. doi: 10.1016/j.tracli.2020.10.012

127. Birjandi MM, Oroei M. The prevalence of positive rapid diagnostic test of hepatitis C virus infection in Ghana. Pan Afr Med J. (2020) 36:322. doi: 10.11604/pamj.2020.36.322.22490

128. Posuwan N, Wanlapakorn N, Sintusek P, Wasitthankasem R, Poovorawan K, Vongpunsawad S, et al. Towards the elimination of viral hepatitis in Thailand by the year 2030. J Virus Erad. (2020) 6:100003. doi: 10.1016/j.jve.2020.100003

129. Gheorghe L, Iacob S, Csiki IE, Huiban L, Cojocaru M, Cojocariu C, et al. The prevalence of HCV infection and risk factors in a hospital- based population screening, a first step to the micro-elimination of HCV infection in medical institutions from Romania - results of the HepC ALERT study. J Gastrointestin Liver Dis. (2020) 29:587-93. doi: 10.15403/jgld-3084

130. World Health Organization. Antigen-Detection in the Diagnosis of SARSCoV-2 Infection Using Rapid Immunoassays (2020). Available online at: https://www.who.int/publications/i/item/antigen-detection-in-thediagnosis-of-sars-cov-2infection-using-rapid-immunoassays (accessed May 26, 2021).

131. Benzaken AS, Bazzo ML, Galban E, Pinto ICP, Nogueira CL, Golfetto L, et al. External quality assurance with dried tube specimens (DTS) for pointof-care syphilis and HIV tests: experience in an indigenous populations screening programme in the Brazilian Amazon. Sex Transm Infect. (2014) 90:14-8. doi: 10.1136/sextrans-2013-051181
132. World Health Organization. WHO Guidelines on Hepatitis B and C Testing. Geneva: World Health Organization (2017).

133. World Health Organization. Hepatitis $C$ (2021). Available online at: https:// www.who.int/news-room/fact-sheets/detail/hepatitis-c (accessed April 29, 2021).

134. Bereket-Yücel S. Risk of hepatitis B infections in Olympic wrestling. Br J Sports Med. (2007) 41:306-10. doi: 10.1136/bjsm.2006. 032847

135. Takata K, Yamauchi E, Shakado S, Uehara Y, Fukuda H, Yamauchi R, et al. Horizontal transmission of hepatitis B virus genotype $\mathrm{C}$ among members of a wrestling club in Japan. Am J Case Rep. (2020) 21:e925044. doi: 10.12659/AJCR.9 25044

Conflict of Interest: The authors declare that the research was conducted in the absence of any commercial or financial relationships that could be construed as a potential conflict of interest.

Publisher's Note: All claims expressed in this article are solely those of the authors and do not necessarily represent those of their affiliated organizations, or those of the publisher, the editors and the reviewers. Any product that may be evaluated in this article, or claim that may be made by its manufacturer, is not guaranteed or endorsed by the publisher.

Copyright (c) 2021 Shenge and Osiowy. This is an open-access article distributed under the terms of the Creative Commons Attribution License (CC BY). The use, distribution or reproduction in other forums is permitted, provided the original author(s) and the copyright owner(s) are credited and that the original publication in this journal is cited, in accordance with accepted academic practice. No use, distribution or reproduction is permitted which does not comply with these terms. 